University of Nebraska - Lincoln

DigitalCommons@University of Nebraska - Lincoln

Faculty Publications from the Harold W. Manter Laboratory of Parasitology

2009

Nagmia rodmani n. sp., Nagmia cisloi n. sp. and Probolitrema richiardii (López, 1888) (Gorgoderidae: Anaporrhutinae) from Elasmobranchs in the Gulf of California, Mexico

\author{
Stephen S. Curran \\ Gulf Coast Research Laboratory, stephen.curran@usm.edu \\ Charles K. Blend \\ Gordon College, chuck.blend@gordon.edu \\ Robin M. Overstreet \\ Gulf Coast Research Laboratory, robin.overstreet@usm.edu
}

Follow this and additional works at: https://digitalcommons.unl.edu/parasitologyfacpubs

Part of the Parasitology Commons

Curran, Stephen S.; Blend, Charles K.; and Overstreet, Robin M., "Nagmia rodmani n. sp., Nagmia cisloi n. sp. and Probolitrema richiardii (López, 1888) (Gorgoderidae: Anaporrhutinae) from Elasmobranchs in the Gulf of California, Mexico" (2009). Faculty Publications from the Harold W. Manter Laboratory of Parasitology. 434.

https://digitalcommons.unl.edu/parasitologyfacpubs/434

This Article is brought to you for free and open access by the Parasitology, Harold W. Manter Laboratory of at DigitalCommons@University of Nebraska - Lincoln. It has been accepted for inclusion in Faculty Publications from the Harold W. Manter Laboratory of Parasitology by an authorized administrator of DigitalCommons@University of Nebraska - Lincoln. 


\title{
Nagmia rodmani n. sp., Nagmia cisloi n. sp., and Probolitrema richiardii (López, 1888) (Gorgoderidae: Anaporrhutinae) from Elasmobranchs in the Gulf of California, Mexico
}

\author{
Stephen S. Curran, ${ }^{1,3}$ Charles K. Blend, ${ }^{2}$ and Robin M. Overstreet ${ }^{1}$ \\ ${ }^{1}$ Department of Coastal Sciences, The University of Southern Mississippi, 703 East Beach Drive, Ocean Springs, \\ Mississippi 39564, U.S.A. (e-mail: stephen.curran@usm.edu; robin.overstreet@usm.edu) and \\ 2 Department of Biology, Gordon College, 255 Grapevine Road, Wenham, Massachusetts 01984-1899, U.S.A. \\ (e-mail chuck.blend@gordon.edu)
}

ABSTRACT: The generic diagnosis of Nagmia Nagaty, 1930, is emended to include species having some vitelline follicles extending into the extracecal space. Two new species belonging in the genus are described from the Gulf of California: Nagmia rodmani $\mathrm{n}$. sp. from the body cavity of the giant electric ray, Narcine entemedor Jordan and Starks, 1895, and Nagmia cisloi $\mathrm{n}$. sp. from the body cavity of the smoothtail mobula, Mobula thurstoni (Lloyd, 1908). Both species are distinguished from each other and the 13 other known congeners by the number of testicular follicles, ratio of widths of oral sucker to ventral sucker, and position of the vitelline follicles relative to the ceca. Nagmia rodmani is distinct based on the combined features: $12-17$ follicles per testis, sucker width ratio of 1:1.7-2.0, vitelline follicles extending into the extracecal space, and the excretory vesicle being I-shaped and lacking perpendicular lateral branches along the main stem. Nagmia cisloi is distinct based on the combined features: 23-26 follicles per testis, body measuring $13.4 \mathrm{~mm}$ long by $14.6 \mathrm{~mm}$ wide, eggs measuring $47-48 \mu \mathrm{m}$ long by $43-47 \mu \mathrm{m}$ wide, and the excretory vesicle is I-shaped and has lateral perpendicular branches along the main stem. Supplemental data are provided for the anaporrhutine species Probolitrema richiardii (López, 1888) collected from a variety of rays in the Gulf of California. Our specimens are indistinguishable from those described as Probolitrema californiense Stunkard, 1935, and Probolitrema mexicana Markell (1956), both of which previously had been synonymized under $P$. richiardii. Checklists of parasites reported from N. entemedor and M. thurstoni are provided.

KEY WORDS: Digenea, Gorgoderidae, Anaporrhutinae, Nagmia rodmani n. sp., Nagmia cisloi n. sp., Probolitrema richiardii, Narcine entemedor, Mobula thurstoni, parasites, elasmobranchs, Gulf of California, Mexico.

Gorgoderids in the subfamily Anaporrhutinae Looss, 1901, are large trematodes that live in the body cavity of elasmobranchs worldwide. There are arguably 5 anaporrhutine genera, but distinction among these is based on some ambiguous morphological features that are summarized in the discussion. Larval stages are not known for any species in the subfamily. In this paper, we conclude an investigation on the digeneans found in a total of 817 elasmobranchs representing 42 species collected from at least 7 sites along the western shore of the Gulf of California (for collection sites, see Tyler, 2001). Digeneans belonging in Azygiidae Lühe, 1909; Syncoeliidae Looss, 1899; Ptychogonomidae Dollfus, 1937; and Gorgoderidae Looss, 1901, were collected from elasmobranchs during the field study. Species in Azygiidae, Syncoeliidae, and Ptychogonimidae were reported by Curran and Overstreet (2000). A gorgoderid from the collection belonging in Anaporrhutum Ofenheim, 1900, was described by Curran et al. (2003). Herein, the remaining gorgoderid mate-

\footnotetext{
${ }^{3}$ Corresponding author.
}

rial from the collection is investigated and 2 new species of Nagmia Nagaty, 1930, are described: 1 from the giant electric ray, Narcine entemedor Jordan and Starks, 1895, the second from the smoothtail mobula, Mobula thurstoni (Lloyd, 1908). Supplemental data are provided for the only other gorgoderid species encountered, Probolitrema richiardii (López, 1888), from a variety of hosts.

\section{MATERIALS AND METHODS}

Gorgoderids were collected from the body cavity of rays obtained from commercial gill-netters or collected with hand spears during a survey of the metazoan parasites of elasmobranchs in the Gulf of California (see Tyler, 2001). Specimens of Nagmia floridensis Markell, 1953, were collected from the Atlantic stingray, Dasyatis sabina (Lesueur, 1824), from the Mississippi Sound off Biloxi, Mississippi, U.S.A., for comparative purposes. Gorgoderids were removed from the body cavity and killed with near boiling water. Killed specimens collected in Mexico were placed in 10\% formalin buffered in seawater, and those killed in Mississippi were placed in $10 \%$ formalin buffered with monobasic and dibasic sodium phosphate. Worms in formalin solution were washed and then stained in aqueous Van Cleave's hematoxylin and prepared following the protocol of Curran et al. (2003). Measurements are ranges 
in $\mu \mathrm{m}$ unless indicated otherwise. Taxonomic terms follow those by Manter (1970). Ecological terms follow those by Bush et al. (1997). Names of fish are from the checklist of Nelson et al. (2004) or the catalogue by Eschmeyer (1998). Illustrations were made with the aid of a drawing tube. Specimens are deposited in the Instituto de Biología, Universidad Nacional Autónoma de México (IBUNAM, CNHE), Mexico City, Mexico; at the Harold W. Manter Laboratory (HWML) of the University of Nebraska State Museum in Lincoln, Nebraska, U.S.A.; and the Santa Barbara Museum of Natural History (SBMNH) in Santa Barbara, California, U.S.A.

\section{Nagmia}

\section{Diagnosis}

Modified from diagnoses of Yamaguti (1971) and Brooks and Mattis (1978). Gorgoderidae, Anaporrhutinae. Body large; subdivided into relatively small forebody and circular or subcircular hindbody; hindbody dorsoventrally flattened or concave ventrally and convex dorsally. Tegument lacking spines. Oral sucker terminal with subterminal mouth. Prepharynx absent. Pharynx prominent. Esophagus about as long as pharynx. Ventral sucker about one third of body length from anterior end. Intestine bifurcating in forebody. Ceca with irregular margins, terminating blindly in posterior fourth of body. Testes consisting of opposing, extracecal grapelike bunches of follicles in hindbody; bunches with more than 3 follicles, with each follicle associated with a single tertiary sperm duct; tertiary sperm ducts uniting, forming secondary sperm duct; secondary sperm ducts uniting as vasa efferentia on each side of body; vasa efferentia converging, forming single male duct. Seminal vesicle elongated. Pars prostatica present. Ejaculatory duct short, unarmed. Cirrus and cirrus sac absent. Genital atrium indistinct. Genital pore medial, immediately posterior to cecal bifurcation (with the exception in Nagmia pacifica [Caballero, 1945], which has the genital pore at level of pharynx). Ovary submedian, amphitypic. Seminal receptacle submedian, immediately preovarian, larger than ovary. Laurer's canal absent. Vitellarium consisting of opposing ventral fields of tubular or dendritic follicles, each connecting to a common reservoir through 2 opposing vitelline ducts; vitelline fields intercecal or with some tubules extending into cecal space or extracecal space; reservoir median or submedian, adjacent to and communicating with ootype. Mehlis' gland present. Uterus intercecal. Eggs with well-developed embryos, thin-shelled, with indistinct operculum. Excretory vesicle I-shaped; main stem either lacking branches or having multiple perpendicular lateral branches; excretory pore terminal or subterminal. Parasitic in the body cavity or pericardium of marine elasmobranchs. Type species Nagmia yorkei Nagaty, 1930.

\section{Nagmia rodmani n. sp. (Figs. 1-3)}

\section{Description}

Based on 10 adult specimens. Body flat, pyriform, 4.6-11.0 $\mathrm{mm}$ long, 4.4-9.3 mm wide. Oral sucker 470-802 long, 619-1,062 wide. Pharynx 219-407 long, 313-583 wide. Esophagus sinuous, 250-400 long. Ventral sucker 897-1,699 long, 1,027-2,195 wide. Ratio of oral sucker width to ventral sucker width 1:1.7-2.0. Forebody 1,179-2,807 long, representing $22-33 \%$ of body length. Hindbody 2,5546,933 long, representing $47-61 \%$ of body length.

Testes follicular, in posterior half of body; left testicular field comprising 12-17 follicles, with entire field measuring 991-2,761 long, representing 17$26 \%$ of body length; right testicular field comprising 14-17 follicles, with entire field measuring 1,1092,690 long, representing $16-26 \%$ of body length (1 exceptional specimen had both fields measuring $32 \%$ of body length). Seminal vesicle elongated, looping, intercecal, preacetabular or partially overlapping ventral sucker dorsally; proximal end 5966 wide, distal end 121-250 wide. Pars prostatica 156-274 long, 85-152 wide. Ejaculatory duct 59117 long, opening into small genital atrium; genital atrium surrounded by gland cells. Genital pore opening medial, immediately posterior to cecal bifurcation.

Ovary irregular or subspherical, 258-548 long, 376-642 wide. Seminal receptacle thin walled, 5171,086 long, 587-1,154 wide. Vitelline follicles tubular; tubules in 2 ventrolateral fields; fields 3751,487 long, 401-920 wide, with most tubules straddling ceca but some extending into extracecal space; direct distance between left and right vitelline fields $2,891-3,481$, representing $38-44 \%$ of body width in 8 individuals greater than $8 \mathrm{~mm}$ long and $33-34 \%$ of body width in 2 individuals less than $8 \mathrm{~mm}$ long. Vitelline reservoir immediately preovarian. Mehlis' gland dorsal to vitelline reservoir. Uterus confined to intercecal space; distal portion extending into forebody, with walls forming short metraterm; metraterm lying ventral to male duct, opening into genital atrium. Eggs 39-62 long, 25-47 wide in metraterm.

Excretory vesicle I-shaped, extending nearly to level of ovary, lacking perpendicular lateral branches; excretory pore opening into groove at terminal end of body. 


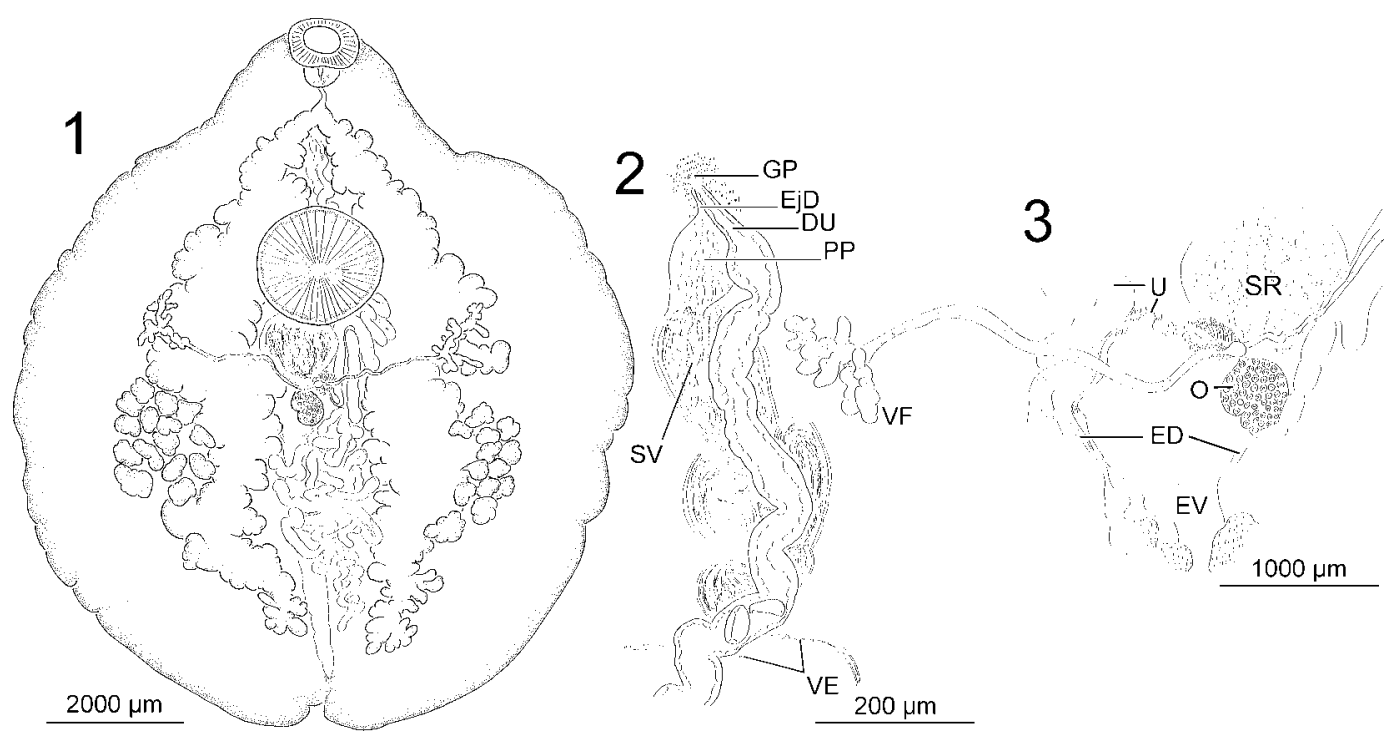

Figures 1-3. Nagmia rodmani n. sp. 1. Ventral view of holotype from body cavity of Narcine entemedor (Narcinidae) from off Loreto, Gulf of California, Mexico. 2. Ventral view of terminal genitalia from a paratype specimen from $N$. entemedor from the type locality. 3. Dorsal view of ovarian complex of paratype from separate specimen of $N$. entemedor from the type locality. (DU, distal portion of uterus, or metraterm; ED, collecting ducts of excretory system; $\mathrm{EjD}$, ejaculatory duct obscured by distal portion of ventral metraterm; EV, excretory vesicle; GP, genital pore; O, ovary; PP, pars prostatica; SR, seminal receptacle; SV, seminal vesicle; U, uterus; VE, vasa efferentia; VF, vitelline follicles.).

\section{Taxonomic Summary}

Type host: Giant electric ray, N. entemedor (Narcinidae).

Type locality: Gulf of California, near Loreto, Mexico $\left(26^{\circ} 04^{\prime} 04^{\prime \prime} \mathrm{N}, 111^{\circ} 12^{\prime} 31^{\prime \prime} \mathrm{W}\right)$.

Site of infection: Body cavity.

Prevalence of infection: $100 \%$ (3 fish examined).

Mean intensity of infection: 6.7 worms per infection (ranging from 3 to 10 worms per infection).

Specimens deposited: Holotype IBUNAM, CNHE No. 6199; 1 Paratype HWML No. 48889; 1 Paratype SBMNH 423115.

Etymology: The specific name rodmani refers to James Rodman (National Science Foundation) in recognition of his appreciation of, and dedication to, taxonomic research.

\section{Remarks}

Nagaty (1930) erected Nagmia for species of Anaporrhutinae with large numbers of testicular follicles in opposing extracecal clusters and with vitelline fields in the intercecal space. Yamaguti (1971) considered the ceca to be diverticulate, but we consider the ceca to have irregular margins instead. Yamaguti (1971) described the excretory vesicle as being tubular, with or without side branches. We, like Brooks and Mattis (1978), prefer to call the excretory vesicle I-shaped, and we called the side branches of Yamaguti (1971) perpendicular lateral branches associated with the bladder. Brooks and Mattis (1978) refined the diagnosis of Nagmia to include species with vitelline follicles that extend at least partially into the extracecal space. While no single feature serves to differentiate Nagmia from other anaporrhutine genera, collectively, the number of testicular follicles, location of the vitelline fields, irregular cecal margins, and the type of excretory vesicle effectively distinguish the genus (Nagaty, 1930; Markell, 1953a; Brooks and Mattis, 1978; Curran et al., 2003).

Nagmia rodmani $\mathrm{n}$. sp. differs from the 13 recognized species in Nagmia. These are N. yorkei, Nagmia larga (Lühe, 1906), and Nagmia yamagutia Tandon, 1969, from the Indian Ocean; Nagmia concolori (Nagaty and Abdel-Aal, 1961), Nagmia nebrii Nagaty and Abdel-Aal, 1961, and Nagmia stegostomatis (Nagaty and Abdel-Aal, 1961) from the Red 
Sea; Nagmia rosettensis Melouk, 1940, from the Mediterranean Sea off northern Egypt; Nagmia africana Fischthal and Thomas, 1972, Nagmia senegalensis Fischthal and Thomas, 1972, and Nagmia trygonis (Dollfus, 1971) from the eastern tropical Atlantic Ocean off Senegal; N. pacifica and Nagmia peruviana Tantalean and Rodriguez, 1990, from the eastern Pacific Ocean; and N. floridensis from the Gulf of Mexico. Given the rarity, poor fixation of specimens, and low number of specimens examined in most records concerning these species (i.e., Lühe, 1906; Nagaty, 1930; Melouk, 1940; Markell, 1953a; Nagaty and Abdel-Aal, 1961; Tandon, 1969; Dollfus, 1971; Fischthal and Thomas, 1972; Tantalean and Rodriquez, 1990), additional material and or molecular evaluation could modify this list.

We differentiated $N$. rodmani from most of its 13 congeners on the basis of the location of the vitelline tubules. In some species the vitelline tubules are entirely intercecal (e.g., N. yorkei, N. larga, $N$. pacifica, $N$. concolori, N. nebrii, N. stegostomatis, and $N$. peruviana); in some they are largely intercecal with some follicles ventrally overlapping the ceca (e.g., $N$. rosettensis, $N$. africana, $N$. senegalensis, and $N$. yamagutia). Only specimens of $N$. floridensis, $N$. trygonis, and $N$. rodmani have at least some vitelline tubules that extend into the extracecal space. Essentially, these 3 species have relatively longer vitelline ducts compared with other species in Nagmia. Nagmia rodmani is very similar to $N$. floridensis in size and overall body shape, and the range in length of the testicular field relative to overall body length is identical for both species (16-26\% in N. rodmani and in all 10 specimens of $N$. floridensis we collected from D. sabina in the Mississippi Sound). Nagmia rodmani differs from $N$. floridensis by having 12-17 testicular follicles per field compared with 13-30 reported by Brooks and Mattis (1978) and 17-27 in our specimens of $N$. floridensis. The ratio of the oral sucker width to ventral sucker width is 1:1.7-2.0 in N. rodmani compared with 1:1.2-1.7 in N. floridensis (Markell, 1953a; Brooks and Mattis, 1978). Nagmia rodmani and $N$. floridensis also differ slightly by the configuration of the vitellarium. The right and left vitelline foci, the points of divergence of vitelline tubules from the primary ducts, in $N$. rodmani are $2,891-3,481 \mu \mathrm{m}$ apart, ranging from $38-44 \%$ of the body width. The vitelline foci in our 10 specimens of $N$. floridensis are 1,628-2,470 $\mu \mathrm{m}$ apart, representing $22-34 \%$ of the body width. Consequently, the relatively longer distance between the vitelline fields in
$N$. rodmani provides a good differentiating feature. Nagmia floridensis has been reported from a variety of coastal rays in the Gulf of Mexico (Markell, 1953a; Brooks and Mattis, 1978; present study). We have also collected $N$. floridensis from the cownose ray, Rhinoptera bonasus (Mitchill, 1815), off Mississippi, U.S.A. (Olson et al., 2003). The distribution of $N$. rodmani and $N$. floridensis on opposite sides of Central America suggests to us that the 2 species may be sister taxa whose ancestral population may have become isolated by closing of the Panamanian Isthmus approximately 3.5-3.1 million years ago (Coates and Obando, 1996).

Nagmia rodmani differs from $N$. trygonis by having a smaller body (4.6-11.0 mm long, 4.4$9.3 \mathrm{~mm}$ wide compared with $13-18.5 \mathrm{~mm}$ long, $12.5-$ $17.0 \mathrm{~mm}$ wide) and a lower sucker width ratio (1:1.7-2.0 compared with 1:2.0-3.6). Dollfus (1971) had only 2 specimens of $N$. trygonis, which he originally described as Nagmioides trygonis Dollfus, 1971, from the marbled stingray, Trygon marmorata Steindachner, 1892 (=Dasyatis marmorata [Steindachner, 1892]), off Senegal in western Africa. Brooks and Mattis (1978) declared Nagmioides Dollfus, 1971, a junior synonym of Nagmia, a decision with which we agree. Fischthal and Thomas (1972) described $N$. senegalensis based on specimens collected from the same host, D. marmorata, off Senegal, and did not compare their specimens with $N$. trygonis. A thorough comparison between $N$. trygonis and $N$. senegalensis requires an investigation of more specimens. Nagmia rodmani differs from $N$. senegalensis by lacking 5 anterior lobes on the pharynx and because the vitelline follicles extend into the extracecal space rather than being intercecal and overlapping the ceca.

Obvious morphological differences exist among the 3 species from the eastern Pacific Ocean: $N$. rodmani, $N$. pacifica, and $N$. peruviana. Nagmia rodmani differs from both species with which it is sympatric by having the vitelline tubules extending into the extracecal space rather than being entirely intercecal. Nagmia rodmani differs from $N$. pacifica by having the genital pore opening immediately posterior to the intestinal bifurcation rather than at the pharyngeal level. Tantalean and Rodriguez (1990) described $N$. peruviana from the smoothtail mobula, Mobula lucasana Beebe and Tee-Van, 1938 ( $=$ M. thurstoni), off Peru; N. rodmani differs from it by having fewer testicular follicles per field (12-17 compared with 21-35) and a smaller testicular field length (17-26\% of body length compared with $42-44 \%$ of body length). 


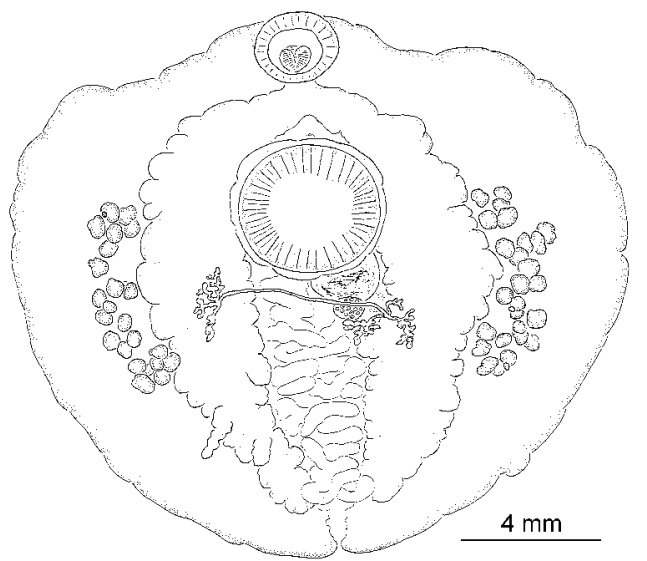

Figure 4. Nagmia cisloi n. sp., ventral view of holotype from body cavity of Mobula thurstoni (Myliobatidae) from the Gulf of California, Mexico. Ventral sucker obscures observation of terminal genitalia.

\section{Nagmia cisloi n. sp.} (Fig. 4)

\section{Description}

Based on 1 adult specimen with anterior end slightly curled ventrally. Body flat, pyriform, 13.4 $\mathrm{mm}$ long (estimated due to curl), $14.6 \mathrm{~mm}$ wide. Oral sucker 1,935 long, 2,313 wide. Pharynx 873 wide. Esophagus sinuous, approximately 400 long. Ventral sucker 3,729 long, 4,012 wide. Ratio of oral sucker width to ventral sucker width $1: 1.7$. Forebody 3,511 long, representing approximately $26 \%$ of body length. Hindbody 8,556 long, representing approximately $64 \%$ of body length.

Testes follicular in middle third of body; left testicular field comprising 26 follicles with field measuring 5,074 long, representing 38\% of body length; right testicular field comprising 23 follicles with field measuring 5,192 long, representing 39\% of body length; follicles lobed or entire, 235-556 wide. Seminal vesicle obscured, 786 wide at widest observable part. Pars prostatica roughly spindle shaped, 371 wide (length not clearly measurable). Ejaculatory duct (length not clearly measurable), emptying into genital atrium. Genital pore medial, opening immediately anterior to ventral sucker.

Ovary subspherical, submedian on left side, 556 long, 767 wide. Seminal receptacle thin walled 1,416 long, 1,581 wide. Vitelline follicles tubular; tubules in 2 opposing ventral fields at ovarian level; left field 1,982 long, 755 wide; right field 1,369 long, 2,006 wide. Vitelline tubules overlapping ceca but not extending into extracecal space. Direct distance between left and right vitelline fields $4.4 \mathrm{~mm}$, representing $30 \%$ of body width. Vitelline reservoir occurring lateral to ovary on left side. Uterus confined to intercecal space; distal portion extending dorsal to ventral sucker and into forebody, with walls forming a metraterm; metraterm lying ventral to male duct, opening into genital atrium. Eggs 47-48 long, 43-47 wide in metraterm.

Excretory vesicle presumably I-shaped, anterior extent not observed. Posterior region of main stem with perpendicular lateral branches on both sides; excretory pore slightly subterminal, dorsal.

\section{Taxonomic Summary}

Type host: Smoothtail mobula, M. thurstoni (Myliobatidae).

Type locality: Gulf of California, off La Paz, Baja California Sur, Mexico $\left(24^{\circ} 12^{\prime} 24^{\prime \prime} \mathrm{N}, 110^{\circ} 25^{\prime} 04^{\prime \prime} \mathrm{W}\right)$.

Site of infection: Body cavity.

Prevalence of infection: 50\% (2 fish examined).

Mean intensity of infection: 1 worm per infection.

Specimen deposited: Holotype IBUNAM, CNHE No. 6198.

Etymology: The name cisloi honors Paul R. Cislo (Yale University), an exceptional teacher and biologist who played a major role in the collection of the material used in this work.

\section{Remarks}

Nagmia cisloi n. sp. is described from a single specimen that was slightly curled ventrally at the level of the oral sucker. Despite this, we consider the specimen to differ so dramatically from other species of Nagmia that we are comfortable naming the new species. Nagmia cisloi may be distinguished from the congeners found in the Indian Ocean, Red Sea, and Mediterranean Sea based on differences in 1 or more important specific features: testicular follicle number, sucker width ratio, body size, and egg size. Nagmia cisloi and $N$. rosettensis from the Mediterranean Sea have only a slightly different number of testicular follicles per lateral field (23-26 compared with 18-22 for $N$. rosettensis) but $N$. cisloi has a larger body (13.4 $\mathrm{mm}$ long by $14.6 \mathrm{~mm}$ wide compared with 7-9 $\mathrm{mm}$ long by $6-8 \mathrm{~mm}$ wide), and smaller eggs (47-48 $\mu \mathrm{m}$ long by $43-47 \mu \mathrm{m}$ wide compared with $66 \mu \mathrm{m}$ long by $62 \mu \mathrm{m}$ wide) (Melouk, 1940). Nagmia cisloi has fewer testicular follicles per field (23-26) and smaller eggs ( $47-48 \mu \mathrm{m}$ long by $43-47 \mu \mathrm{m}$ wide) 
than $N$. yorkei from the Indian Ocean, which has 2935 testicular follicles per field and eggs measuring 96 $\mu \mathrm{m}$ long by $48 \mu \mathrm{m}$ wide (Nagaty, 1930). Nagmia cisloi has more testicular follicles per field (23-26) and a smaller sucker width ratio (1:1.7) than $N$. larga from the Indian Ocean, where the species has 14-16 testicular follicles per field and a sucker width ratio of 1:2.8 (see Baylis, 1927) and smaller eggs than $N$. yamagutia, the other species from the Indian Ocean, where the species has eggs measuring 60-75 $\mu \mathrm{m}$ long by $48-55 \mu \mathrm{m}$ wide (Tandon, 1969). Nagmia cisloi differs from the 3 species found in the Red Sea $(N$. concolori, $N$. nebrii, and N. stegostomatis) by having smaller, rounder eggs measuring $47-48 \mu \mathrm{m}$ long by 43-47 $\mu \mathrm{m}$ wide compared with $60 \mu \mathrm{m}$ long by $30 \mu \mathrm{m}$ wide for these 3 species (Nagaty and Abdel-Aal, 1961).

Nagmia cisloi is larger in body size ( $13.4 \mathrm{~mm}$ long, $14.6 \mathrm{~mm}$ wide) than either $N$. africana $(3.7-5.6 \mathrm{~mm}$ long by $3.0-5.0 \mathrm{~mm}$ wide) or $N$. senegalensis (4.9$12.0 \mathrm{~mm}$ long by $2.5-10.5 \mathrm{~mm}$ wide), both from the eastern Atlantic Ocean (see Fischthal and Thomas, 1972), and differs from N. trygonis, a third eastern Atlantic species, by having smaller rounder eggs measuring $47-48 \mu \mathrm{m}$ long by $43-47 \mu \mathrm{m}$ wide compared with $49-70 \mu \mathrm{m}$ long by $30-40 \mu \mathrm{m}$ wide, and having the vitelline fields farther apart in $N$. trygonis, measuring $6.6 \mathrm{~mm}$, representing $39 \%$ of body width compared with $4.4 \mathrm{~mm}$, representing $30 \%$ of body width in N. cisloi (see Dollfus, 1971). Also, the vitelline tubules extend at least partially into the extracecal space in $N$. trygonis, compared with overlapping the ceca in $N$. cisloi.

Nagmia cisloi most closely resembles the 3 species in the eastern Pacific Ocean: N. pacifica, N. rodmani, and $N$. peruviana; and $N$. floridensis from the western Atlantic Ocean. Nagmia cisloi and N. pacifica are about the same size, but $N$. cisloi has about twice as many testicular follicles per field (23-26 compared with 9-13) and the genital pore is located immediately posterior to the intestinal bifurcation rather than at pharynx level (Lamothe-Argumedo, 1969). Nagmia pacifica is the only species in the genus that has the genital pore located so far anteriorly. Additionally, the 2 species have approximately the same sucker width ratio (1:1.7), but $N$. cisloi has larger suckers with the oral sucker measuring $1,935 \mu \mathrm{m}$ long by $2,313 \mu \mathrm{m}$ wide and the ventral sucker measuring $3,729 \mu \mathrm{m}$ long by $4,012 \mu \mathrm{m}$ wide compared with an oral sucker measuring 510-983 $\mu \mathrm{m}$ long by $907-945 \mu \mathrm{m}$ wide and a ventral sucker measuring 1,021-1,644 $\mu \mathrm{m}$ long by $1,134-1,758 \mu \mathrm{m}$ wide (Caballero, 1945). Since our specimen was heat fixed without pressure, fixation artifact does not explain the relatively larger sucker sizes in $N$. cisloi. Nagmia cisloi differs from $N$. rodmani by having about twice as many testicular follicles per field (2326 compared with 12-17) and a relatively shorter distance between the vitelline fields (30\% of body width compared with $38-44 \%$ in N. rodmani). Nagmia cisloi has about the same number of testicular follicles per field (23-26 compared with 13-30) as N. floridensis from the Gulf of Mexico, and about the same distance between vitelline fields (30\% compared with $22-34 \%$ of body width), but specimens of $N$. cisloi have relatively longer testicular follicle fields relative to body length (38-39\% compared with $16-26 \%$ of body length in $N$. floridensis). In addition, the sucker width ratio is 1:1.7 in $N$. cisloi compared with 1:1.2-1.7 in N. floridensis. Nagmia cisloi occurs in the same host, M. thurstoni, and shares the same number of testicular follicles per field as the remaining species, $N$. peruviana, but relative testicular field length appears to be greater in N. peruviana (42-44\% compared with $38-39 \%$ of body length). Additionally, the hindbody is broadly circular and the sucker width ratio is $1: 1.7$ in $N$. cisloi, whereas the hindbody is oval and the sucker width ratio is $1: 1.3$ in $N$. peruviana. Tantalean and Rodriguez (1990) fixed their specimens of $N$. peruviana with unheated $10 \%$ formalin with pressure; consequently, the features that distinguish $N$. cisloi from $N$. peruviana may be distorted. Specimens of $N$. peruviana killed in hot water or hot formalin with no pressure are required for more adequate comparison between the species.

\section{Probolitrema richiardii} (Fig. 5)

Synonyms: Distoma richiardii López, 1888; Anaporrhutum richiardii Looss, 1900; Probolitrema californiense Stunkard, 1935; Probolitrema mexicana Markell (1956).

\section{Supplemental Data}

Based on 7 adult specimens. Body 5.3-9.5 mm long, $4.0-7.5 \mathrm{~mm}$ wide. Tegument smooth. Oral sucker terminal, 548-779 long, 658-1,003 wide. Mouth subterminal. Prepharynx absent. Pharynx 282-470 long, 376-525 wide. Esophagus sinuous, lacking minute diverticula, 250-455 long. Ceca ending blindly near posterior end of body; margins irregular. Ventral sucker in anterior half of body, lacking peduncle, 1,015-1,770 long, 991-1,746 wide. Ratio of oral sucker width to ventral sucker width 1:1.5-1.6. Forebody conical, 1,694-2,381 


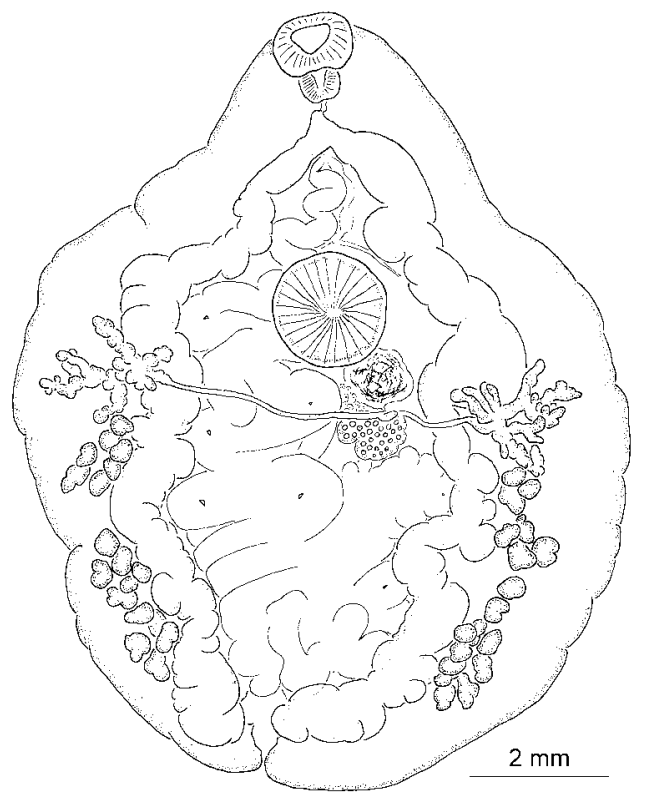

Figure 5. Probilotrema richiardii, ventral view of specimen from the body cavity of Urobatis sp. (Urolophidae) from off Isla San Esteban, Gulf of California, Mexico.

long, representing 23-38\% of body length. Hindbody flat, oval, 2,419-5,546 long, representing 40-62\% of body length.

Testicular follicles extracecal, distributed in 2 opposing elongated fields in hindbody; left testicular field comprising 15-25 follicles, entire field measuring 1,534-3,304 long, representing $26-41 \%$ of body length; right testicular field with 18-25 follicles, entire field measuring 1,510-3,304 long, representing $25-46 \%$ of body length; testicular follicles lobed to entire, 172-415 wide. Vasa efferentia joining at level dorsal to ventral sucker, forming looping elongated seminal vesicle; seminal vesicle 86-101 wide at proximal end, 149-235 wide at greatest width near distal end. Pars prostatica 172-227 long, 117-172 wide. Ejaculatory duct 45-59 long, opening into shallow genital atrium. Genital pore medial, opening immediately posterior to intestinal bifurcation.

Ovary entire or irregular, submedian, amphitypic, 235-603 long, 415-1,002 wide. Seminal receptacle thin walled, preovarian, 564-814 long, 548-940 wide. Mehlis' gland submedian, preovarian. Laurer's canal absent. Vitelline follicles tubular, tubules in 2 ventrolateral fields in middle third of body; fields largely extracecal, 579-1,392 long, 548-1,652 wide. Vitelline reservoir submedian, ventral at posterior margin of seminal receptacle. Uterus intercecal, thin walled, looping; loops descending from ovary and Mehlis' gland to posterior end of body then ascending and extending to genital atrium; distal uterus relatively thick walled, comprising a muscular metraterm. Eggs operculate, thin-shelled, 35-59 long, 23-50 wide in metraterm.

Excretory vesicle not fully observed; longitudinal secondary collecting ducts present lateral to vitelline fields and testes on either side of body; excretory pore opening into small groove at posterior end of body.

\section{Taxonomic Summary}

Hosts: Urobatis sp. (Urolophidae); whiptail stingray, Dasyatis brevis (Garman, 1880), and longtail stingray, Dasyatis longa (Garman, 1880) (Dasyatidae); whitesnout guitarfish; Rhinobatos leucorhynchus Günther, 1867 (Rhinobatidae); bat ray, Myliobatis californica Gill, 1865, and longnose eagle ray, Myliobatis longirostris Applegate and Fitch, 1964 (Myliobatidae).

Localities: Gulf of California, Mexico, off Isla San Esteban $\left(28^{\circ} 44^{\prime} 05^{\prime \prime} \mathrm{N}, 112^{\circ} 38^{\prime} 12^{\prime \prime} \mathrm{W}\right)$; off Bahia de Los Angeles $\left(29^{\circ} 02^{\prime} 10^{\prime \prime} \mathrm{N}, 113^{\circ} 31^{\prime} 30^{\prime \prime} \mathrm{W}\right)$; off Loreto $\left(26^{\circ} 03^{\prime} 14^{\prime \prime} \mathrm{N}, 111^{\circ} 11^{\prime} 46^{\prime \prime} \mathrm{W}\right)$; and off Santa Rosalia $\left(27^{\circ} 17^{\prime} 23^{\prime \prime} \mathrm{N}, 112^{\circ} 08^{\prime} 13^{\prime \prime} \mathrm{W}\right)$.

Site of infection: Body cavity.

Prevalence of infection: Urobatis sp. $=100 \%[n=2]$; D. brevis $=43 \%[n=7] ;$ M. californica $=6 \%[n=$ 15]; M. longirostris $=33 \%[n=3] ;$ D. longa $=50 \%$ $[n=2] ;$ R. leucorhynchus $=100 \%[n=2]$.

Mean intensity of infection: Urobatis sp. $=1.5$ worms per infection; $D$. brevis $=1.33$ worms per infection; $M$. californica $=2$ worms per infection; $M$. longirostris $=1$ worm per infection; $D$. long $a=1$ worm per infection; $R$. leucorhynchus $=2$ worms per infection.

Specimens deposited: Voucher specimen HWML No. 48890; voucher specimen SBMNH 423116; voucher specimen IBUNAM, CNHE No. 6200.

Specimens examined: Probolitrema californiense, holotype from the American Museum of Natural History (AMNH) No. 179; P. californiense, 2 paratypes (AMNH) Nos. 1487.1, 1487.2; P. californiense, 1 voucher specimen (USNPC) No. 82777; P. mexicana, holotype (USNPC) No. 49354.

Notes: The type host for $P$. richiardii is the piked dogfish, Squalus acanthias Linnaeus, 1758, according to López (1888) and Looss (1902). The type locality is the Mediterranean Sea, where the species 
was also reported in Mustelus vulgaris (an invalid name) and the common eagle ray, Myliobatis aquila (Linnaeus, 1758) (see Ofenheim, 1900). Probolitrema richiardii was also reported from the body cavity of a cat shark (Scyllium sp.) from the Atlantic Ocean off Cape Town, South Africa (Ofenheim, 1900). Ofenheim (1900) stated that the species is recorded from the body cavity of its host.

\section{Remarks}

Probolitrema richiardii was originally described as Distoma richiardii. Ofenheim (1900) erected Anaporrhutum Brandes in Ofenheim, 1900, for Anaporrhutum albidum Brandes in Ofenheim, 1900, and made the new combination Anaporrhutum richiardii (López, 1888) for D. richiardii. Looss (1902) erected Probolitrema Looss, 1902, and created the new combination $P$. richiardii for $A$. richiardii. Diagnostic features traditionally used to characterize species in Probolitrema include body size, number of testicular follicles, ratio of oral to ventral sucker width, and egg size; however, Gibson (1976) found these features inadequate for distinguishing species. Furthermore, Gibson (1976) pointed out that many of the species were described before the first adequate description of the type species, $P$. richiardii, was made available by Dollfus (1937) for comparison. Consequently, Gibson (1976) considered all 10 named species in Probolitrema to be junior synonyms of $P$. richiardii. We tentatively agree with Gibson's (1976) decision until comparisons of life history or molecular data from the various forms are conducted.

Prior to Gibson's (1976) amalgamation of the species assigned to Probolitrema, 2 species from the eastern Pacific Ocean were given names: P. californiense and $P$. mexicana Markell, 1956. Stunkard (1935) reported P. californiense from M. californica in Monterey Bay, California, U.S.A., and Markell (1953b) reported $P$. californiense from the thornback, Platyrhinoidis triseriata (Jordan and Gilbert, 1880), and the shovelnose guitarfish, Rhinobatos productus Ayres, 1854, from off La Jolla, California, U.S.A. Stunkard (1935) contended that the main differentiating feature for $P$. californiense was a bipartite seminal vesicle, but Markell (1953b) refuted the presence of a bipartite seminal vesicle in his redescription of $P$. californiense, but he still accepted the species as valid. We examined the holotype (AMNH 179) and 2 paratypes (AMNH 1487.1, 1487.2) of $P$. californiense plus 1 voucher specimen (USNPC No. 82777) and did not observe a bipartite seminal vesicle in any of the material examined.
Instead, we found an elongated looping seminal vesicle and a large amount of sperm in the pars prostatica in 2 of the specimens. We suspect Stunkard (1935) considered the pars prostatica to be part of the seminal vesicle. Gibson (1976) noted that the measurements reported for egg size, sucker ratio, and testicular follicle number for $P$. californiense overlapped those reported for $P$. richiardii. Measurements of these 3 features from the specimens examined in the present study were also consistent with those of $P$. richiardii. Markell (1956) reported $P$. mexicana from the sicklefin smoothhound, Mustelus lunulatus Jordan and Gilbert, 1882, Urobatis maculatus Garman, 1913, and D. brevis, in Santa Inez Bay, Baja California, Mexico. He characterized it by the presence of diverticulate to grossly saccate intestinal ceca. We examined the holotype of $P$. mexicana (USNPC 49354) and determined that the cecal margins were irregular and prefer that term to "diverticulate or grossly saccate" since not all diverticula that emerge from the cecal margins are longer than they are wide. Specimens of $P$. richiardii from this study all had ceca with irregular margins like in the holoype for P. mexicana. Looss (1902) and Dollfus (1971) reported that the ceca were saccate and/or diverticulate (which we again refer to as having an irregular margin) in $P$. richiardii and Johnston (1934) also used the term saccate to describe the ceca of Probolitrema rotundatum Johnston, 1934. We conclude from these works and our own observations, as earlier researchers did, that the ceca are normally irregular and may appear smooth in certain individuals presumably due to fixation artifact (i.e., Ofenheim, 1900; Looss, 1902; Johnston, 1934; Woolcock, 1935). We advocate that the condition of the ceca should not be used as a specific-level feature for species of Probolitrema. Furthermore, we agree with Gibson (1976) and consider $P$. californiense and $P$. mexicana as junior synonyms of $P$. richiardii.

\section{DISCUSSION}

Narcine entemedor, the type host for N. rodmani, is a coastal ray that occurs in the eastern Pacific Ocean from Mexico to Peru, and M. thurstoni, the type host for $N$. cisloi, is a ray with a circumtropical distribution between $38^{\circ} \mathrm{N}$ and $34^{\circ} \mathrm{S}$ (Froese and Pauly, 2007). Anaporrhutine species have been reported from both rays, but notably, no anaporrhutine species has been reported from M. thurstoni outside the eastern Pacific Ocean. Checklists are included below for parasites reported from both ray species. 
Anaporrhutinae comprises the 5 genera Anaporrhutum, Nagmia, Petalodistomum Johnston, 1913, Probolitrema, and Staphylorchis Travassos, 1922. Stunkard (1935) and Gibson (1976) each summarized the taxonomic history of Anaporrhutinae. Members of the subfamily are all relatively large flattened gorgoderids that as adults live in the body cavity or pericardium of elasmobranchs. They all have a pharynx, 2 opposing bunches of testicular follicles, a uterus confined to the intercecal region of the hindbody, a vitellarium consisting of 2 opposing fields comprising digitiform or acinous follicles, and the main stem of the excretory vesicle extends to the level immediately posterior to the ovary. There are few features useful for differentiating genera in the subfamily. Species in Anaporrhutum differ from other anaporrhutines by having testicular follicles ventrally straddling the ceca (Looss, 1902; Curran et al., 2003). Species in Nagmia have extracecal testes, vitelline fields ventrally straddling the ceca or entirely intercecal, and ceca with irregular margins. The single species in Petalodistomum, Petalodistomum polycladum Johnston, 1913, has irregular cecal margins and extracecal testes like in species of Nagmia but differs from all other anaporrhutines by having each testis comprising 1 to 3 large masses rather than multiple follicles (Johnston, 1913; Johnston, 1934). Arguably, P. polycladum differs from members of Nagmia only by the number and size of the follicles that make up each testis. Consequently, Nagmia might possibly represent a junior synonym of Petalodistomum, but we hesitated to dwell on this problem here because we lacked material of $P$. polycladum for comparison. The single species in Probolitrema, $P$. richiardii, usually has ceca with irregular margins, and the testicular follicles and vitelline fields are extracecal (Gibson, 1976). Species in Staphylorchis have sinuous ceca, extracecal testes, and intercecal vitelline fields (Johnston, 1934; Markell, 1953a).

Depending on one's interpretation, the shape of the excretory vesicle may be useful or confounding when differentiating genera in Anaporrhutinae. Anaporrhutum albidum, Anaporrhutum euzeti Curran, Blend, and Overstreet, 2003, and probably all species in Anaporrhutum have an $\mathrm{H}$-shaped excretory vesicle (Ofenheim, 1900; Curran et al., 2003). Likewise, species in Staphylorchis have an H-shaped excretory vesicle (Johnston, 1934; Samuel, 1952; Mehra, 1960). The shape of the excretory vesicle is more ambiguous in $P$. richiardii. Offenheim (1900) reported and clearly illustrated a Y-shaped excretory vesicle for $P$. richiardii, similar to one typically found in species in Cryptogonimidae Ward, 1917, or Atractotrematidae Yamaguti, 1939. Gibson (1976) considered $P$. richiardii to have an $\mathrm{H}$-shaped excretory vesicle. Markell (1953b) observed a sectioned specimen of $P$. richiardii and described an elongated excretory vesicle that bifurcates slightly posterior to the ovary, noting that the bifurcated arm on the ovarian side subdivided at least once more, suggesting to us that the excretory vesicle is $\mathrm{H}$-shaped. We agree with Gibson (1976) and consider the excretory vesicle $\mathrm{H}$-shaped in $P$. richiardii with the bifurcating arms being slightly more diagonal in orientation than those in species of Anaporrhutum or Staphylorchis. Petalodistomum polycladum has an I-shaped excretory vesicle equipped with numerous short perpendicular lateral branches emanating from the main stem (Johnston, 1913; Nagaty, 1930). Great variability in the configuration of the excretory vesicle has been reported among species of Nagmia. Nagmia yorkei, like $P$. polycladum, has an I-shaped excretory vesicle with numerous perpendicular lateral branches that extend as far as the inner margin of the ceca (Nagaty, 1930). Similarly, N. senegalensis has an I-shaped excretory vesicle with prominent perpendicular lateral branches, and $N$. rosettensis has an I-shaped excretory vesicle with some indistinct perpendicular lateral branches (Melouk, 1940; Fischthal and Thomas, 1972). Nagmia pacifica has an I-shaped excretory vesicle with smooth walls that lack perpendicular branches (Caballero, 1945). Nagmia africana and $N$. floridensis have an I-shaped excretory vesicle that lacks perpendicular branches (Fischthal and Thomas, 1972; Brooks and Mattis, 1978); N. larga purportedly has a Y-shaped excretory vesicle (Lühe, 1906). Observations of the excretory vesicle were not reported in the descriptions of $N$. nebrii, $N$. stegostomatis, $N$. concolori, $N$. yamagutia, $N$. trygonis, and $N$. peruviana. Nagmia rodmani clearly has an I-shaped excretory vesicle that lacks perpendicular lateral branches, similar to the configuration reported for $N$. africana and N. floridensis. Nagmia cisloi has several perpendicular lateral branches visible in the posterior end of the main stem, thus resembling $P$. polycladum, $N$. yorkei, $N$. senegalensis, and $N$. rosettensis.

Historically, several other genera have been included in Anaporrhutinae. In addition to the 5 genera we recognize, Dollfus (1971) and Gibson (1976) included Pernagmia Nagaty and Abdel-Aal, 1961, and Nagmioides. Nagaty and Abdel-Aal (1961) erected Pernagmia for specimens similar to Nagmia, differing only in the shape of the vitelline follicles and their position relative to the seminal receptacle 
and ovary. Yamaguti (1971) considered this action untenable and referred to Pernagmia as a junior synonym of Nagmia, and we agree. Dollfus (1971) distinguished the genus Nagmioides from Nagmia, as referred to in the remarks above, on the basis that the vitelline fields ventrally straddled the ceca in the former genus but were entirely intercecal in the latter genus; however, Brooks and Mattis (1978) considered Nagmioides a junior synonym of Nagmia because they observed that the vitelline fields ventrally straddled the ceca in $N$. floridensis. We observed that the vitelline fields ventrally straddled the ceca in our specimens of $N$. floridensis as well as in both new species described herein and support the opinion of Brooks and Mattis (1978) that Nagmioides is a junior synonym of Nagmia. Markell (1953a) considered Petalodistomum pacificum Caballero, 1945, to be indistinguishable from species in Nagmia and created the new combination $N$. pacifica for the species. Despite this, Lamothe-Argumedo (1969) erected Winteria Lamothe-Argumedo, 1969, for $P$. pacificum on the basis that the testes and vitelline follicles were shaped differently, the testicular follicles were more numerous, the genital pore opened at the level of the pharynx rather than immediately posterior to the intestinal bifurcation, and the parasite infected a carcharhinid shark and not a skate or ray. As Lamothe-Argumedo (1969) pointed out, the numerous testicular follicles of $W$. pacifica exclude the species from Petalodistomum, and the position of the genital pore is unprecedented for Anaporrhutinae. We acknowledge that the position of the genital pore is aberrant in $N$. pacifica, and testicular follicle number is not a strong feature for differentiating genera in Anaporrhutinae; however, until the position of the genital pore is confirmed from more specimens of $N$. pacifica, and molecular techniques are used to compare specimens of $P$. polycladum, N. pacifica, and other species of Nagmia, controversy will surround this issue. We agree with Markell (1953a) for the present and consider this species to belong in Nagmia as N. pacifica.

\section{CHECKLIST OF PARASITES PREVIOUSLY REPORTED FROM NARCINE ENTEMEDOR}

\section{Cestoda}

Acanthobothrium franus Marques, Centritto, and Stewart, 1997

Site of infection: Spiral valve.

Distribution: Costa Rica.
Reports: Marques et al., 1997; Ghoshroy and Caira, 2001; Campbell and Beveridge, 2002.

\section{Acanthobothrium inbiorium Marques, Centritto, and Stewart, 1997}

Site of infection: Spiral valve.

Distribution: Costa Rica.

Reports: Marques et al., 1997; Ghoshroy and Caira, 2001; Campbell and Beveridge, 2002.

\section{Copepoda}

Taeniacanthodes dojirii Braswell, Benz, and Deets, 2002

Sites of infection: Dorsal and ventral body surfaces.

Distribution: Gulf of California.

Report: Braswell et al., 2002.

\section{Digenea}

\section{Anaporrhutum euzeti}

Sites of infection: Body cavity, pericardial cavity.

Distribution: Gulf of California.

Report: Curran et al., 2003.

\section{Nagmia rodmani n. sp.}

Site of infection: Body cavity.

Distribution: Gulf of California.

Report: Present study.

\section{CHECKLIST OF PARASITES PREVIOUSLY} REPORTED FROM MOBULA THURSTONI

\section{Cestoda}

Hemionchos striatus Campbell and Beveridge, 2006

Site of infection: Spiral valve.

Distribution: Gulf of California.

Report: Campbell and Beveridge, 2006.

\section{Mobulocestus lepidoscolex Campbell and Beveridge, 2006}

Site of infection: Nephridial system.

Distribution: Gulf of California.

Report: Campbell and Beveridge, 2006. 


\section{Mobulocestus mollis Campbell and Beveridge, 2006}

Site of infection: Cloaca.

Distribution: Gulf of California.

Report: Campbell and Beveridge, 2006.

\section{Mobulocestus nephritides Campbell and Beveridge, 2006}

Site of infection: Nephridial system.

Distribution: Gulf of California.

Report: Campbell and Beveridge, 2006.

\section{Copepoda \\ Echthrogaleus disciarai Benz and \\ Deets, 1987}

Site of infection: Dorsal surface of pectoral fin.

Distribution: Gulf of California.

Report: Benz and Deets, 1987.

\section{Entepherus laminipes Bere, 1936}

Site of infection: Brachial filters.

Distribution: Gulf of California.

Report: Benz and Deets, 1988.

\section{Kroeyerina mobulae Deets, 1987}

Site of infection: Nasa lamellae.

Distribution: Gulf of California.

Report: Deets, 1987.

\section{Pupulina brevicauda Wilson, 1952}

Sites of infection: Around mouth, anterior end.

Distribution: California.

Reports: MacGinitie, 1947; Wilson, 1952; Yamaguti, 1963.

Notes: MacGinitie (1947, p. 278) reported that $P$. brevicauda (see Wilson, 1952), parasitic on M. thurstoni, was itself parasitized by a "tiny trematode" mainly on the carapace of the copepod.

\section{Pupulina minor Wilson, 1952}

Site of infection: Around mouth.

Distribution: California.
Reports: MacGinitie, 1947; Wilson, 1952; Yamaguti, 1963.

Notes: Wilson (1952, p. 254-258) did not give an infection site for specimens collected from Mobula lucasana $(=M$. thurstoni $)$; however, she mentioned (p. 255) that conspecific specimens were collected by Bere (1936) from "around the mouth of a devilfish (probably Mobula hypostoma [Bancroft, 1831])."

\section{Digenea}

\section{Nagmia peruviana}

Site of infection: Visceral cavity.

Distribution: Peru.

Reports: Tantalean and Rodriguez, 1990; Tantalean et al., 1992; Luque and Oliva, 1993.

\section{Syncoelium vermilionensis Curran and Overstreet, 2000}

Sites of infection: Gills, gill arches.

Distribution: Gulf of California.

Report: Curran and Overstreet, 2000.

\section{Nagmia cisloi n. sp.}

Site of infection: Body cavity.

Distribution: Gulf of California.

Report: Present study.

\section{ACKNOWLEDGMENTS}

We are grateful to Eric Hochberg (Santa Barbara Museum of Natural History) for providing equipment, library materials, and workspace. Ronnie Palmer (The University of Southern Mississippi) assisted with the preparation of materials used in this study. The Gordon Gunter Library at the Gulf Coast Research Laboratory, Ocean Springs, Mississippi, U.S.A. supplied some literature. We are especially indebted to Janine N. Caira (University of Connecticut) for providing the specimens used in the manuscript and to the researchers and students working in her laboratory or employed on this project, especially George W. Benz (Middle Tennessee State University), Kirsten Jensen (University of Kansas), Ash Bullard (Auburn University), Gaines Tyler (Williams School, New London, Connecticut, U.S.A.), and Loren Caira. John McEachran (Texas A\&M University) and Janine N. Caira identified some fish in this study. We are indebted to Elizabeth 
Borda (American Museum of Natural History) and to Eric Hoberg (United States National Parasite Collection) for loans of specimens. Guillermo Sanchez (The University of Southern Mississippi) and Kirsten Jensen aided with translations of literature. Material is based upon work supported by the National Science Foundation Grants DEB 9300796 and DEB 9521943 to Janine N. Caira and 0529684 to R.M.O. Collections were made under collection permit no. 120496-213-03 issued to Janine N. Caira by the Secretaria de Medio Ambiente Recursos Naturales y Pesca, Mexico.

\section{LITERATURE CITED}

Baylis, H. A. 1927. Notes on three little-known trematodes. Annals of the Magazine of Natural History 19:426433.

Benz, G. W., and G. B. Deets. 1987. Echthrogaleus disciarai sp. nov. (Siphonostomatoida: Pandaridae), a parasite copepod of the devil ray Mobula lucasana Beebe and Tee-Van, 1938 from the Sea of Cortez. Canadian Journal of Zoology 65:685-690.

Benz, G. W., and G. B. Deets. 1988. Fifty-one years later: an update on Entepherus, with a phylogenetic analysis of Cecropidae Dana, 1849 (Copepoda: Siphonostomatoida). Canadian Journal of Zoology 66:856-865.

Bere, R. 1936. Parasitic copepods from Gulf of Mexico fish. American Midland Naturalist 17:577-625.

Braswell, J. S., G. W. Benz, and G. B. Deets. 2002. Taeniacanthodes dojirii n. sp. (Copepoda: Poecilostomatoida: Taeniacanthidae), from Cortez electric rays (Narcine entemedor: Torpediniformes: Narcinidae) captured in the Gulf of California, and a phylogenetic analysis of and key to species of Taeniacanthodes. Journal of Parasitology 88:28-35.

Brooks, D. B., and T. E. Mattis. 1978. Redescription of Nagmia floridensis Markell, 1953 with discussion of the composition of the Anaporrhutinae Looss, 1901 (Digenea: Gorgoderidae). Proceedings of the Helminthological Society of Washington 45:169-171.

Bush, A. O., K. D. Lafferty, J. M. Lotz, and A. W. Shostak. 1997. Parasitology meets ecology on its own terms: Margolis et al. revisited. Journal of Parasitology 83:575-583.

Caballero y C., E. 1945. Hallazgo de una especie nueva del genero Petalodistomum Johnston, 1913 (Trematoda: Gorgoderidae) en los tiburones de las costas de Manzanillo, Colima. Annals of the Instituto de Biologia, Mexico 16:359-365.

Campbell, R. A., and I. Beveridge. 2002. The genus Acanthobothrium (Cestoda: Tetraphyllidea: Onchobothriidae) parasitic in Australian elasmobranch fishes. Invertebrate Systematics 16:237-344.

Campbell, R. A., and I. Beveridge. 2006. Three new genera and seven new species of trypanorhynch cestodes (family Eutetrarhynchidae) from manta rays, Mobula spp. (Mobulidae) from the Gulf of California, Mexico. Folia Parasitologica 53:255-275.

Coates, A. G., and J. A. Obando. 1996. The geologic evolution of the Central American Isthmus. Pages 21-
56 in J. B. C. Jackson, A. F. Budd, and A. G. Coates, eds. Evolution and Environment in Tropical America. The University of Chicago Press, Chicago, Illinois.

Curran, S. S., C. K. Blend, and R. M. Overstreet. 2003. Anaporrhutum euzeti sp. n. (Gorgoderidae: Anaporrhutinae) from rays in the Gulf of California, Mexico. Pages 225-234 in C. Combes and J. Jourdane, eds. Taxonomy, Ecology and Evolution of Metazoan Parasites (Livre homage à Louis Euzet). Tome I. Presses Universitaires de Perpignan, Perpignan, France.

Curran, S. S., and R. M. Overstreet. 2000. Syncoelium vermilionensis sp. n. (Hemiuroidea: Syncoeliidae) and new records for members of Azygiidae, Ptychogonimidae, and Syncoeliidae parasitizing elasmobranchs in the Gulf of California. Pages 117-133 in G. SalgadoMaldonado, A. N. García Aldrete, and V. M. VidalMartínez, eds. Metazoan Parasites in the Neotropics: A Systematic and Ecological Perspective. Instituto De Biología, Universidad Nacional Autónoma de México, Mexico City, Mexico.

Deets, G. B. 1987. Phylogenetic analysis and revision of Kroeyerina Wilson, 1932 (Siphonostomatoida: Kroyeriidae), copepods parasitic on chondrichthyans, with descriptions of four new species and the erection of a new genus, Prokroyeria. Canadian Journal of Zoology 65:2121-2148.

Dollfus, R. 1937. Les trématodes digenea des sélaciens (Plagiostomes) Catalogue par hôtes. Distribution géographique. Annales de Parasitologie 15:57-73.

Dollfus, R. 1971. De quelques Trématodes digénétiques de Sélaciens du Sénégal et considérations anatomiques sur les Anaporrhutinae A. Looss, 1901. Bulletin du l'Institut Fondamental d'Afrique Noire 33:347-370.

Eschmeyer, W. N., editor. 1998. Catalogue of fishes. Three Volumes. California Academy of Sciences, San Francisco. 2905 pp.

Fischthal, J. H., and J. D. Thomas. 1972. Digenetic trematodes of marine fishes from Senegal. Bulletin du l'Institut Fondamental d'Afrique Noire 34:292-322.

Froese, R., and D. Pauly, editors. 2007. FishBase. World Wide Web electronic publication (www.fishbase.org), version October 2007.

Ghoshroy, S., and J. N. Caira. 2001. Four new species of Acanthobothrium (Cestoda: Tetraphyllidea) from the whiptail stingray Dasybatis brevis in the Gulf of California, Mexico. Journal of Parasitology 87:354-372.

Gibson, D. 1976. Monogenea and Digenea from fishes. Discovery Reports 36:179-266.

Johnston, S. J. 1913. On some Queensland trematodes, with anatomical observations and descriptions of new species and genera. A report on the trematodes collected by the Australian Institute of Tropical Medicine during the years 1911 and 1912. Queensland Journal of Medical Science 59:361-400.

Johnston, T. H. 1934. Some Australian anaporrhutine trematodes. Transactions of the Royal Society of South Australia 58:139-148.

Lamothe-Argumedo, R. 1969. Tremátodos de peces IV. Registro de cuatro especies de tremátodos de peces marinos de la costa del Pacífico Mexicano. Annals of the Institute de Biologica, Universidad Nacional Autónoma de México, Serie Zoologia 40:179-194.

Looss, A. 1902. Ueber neue und bekannte Trematoden aus Seeschildkröten. Nebst Erörterungen zur Systematik 
und Nomenclatur. Zoologischen Jahrbüchern. Abtheilung für Systematik, Geographie und Biologie der Thiere 16:411-894.

López, C. 1888. Un distoma probabilmente nuovo. Atti della Societa Toscana di Scienze Naturali Residente in Pisa, Processi Verbali 6:137-138.

Lühe, M. 1906. Report to the Government of Ceylon on the Pearl Oyster Fisheries of the Gulf of Manaar, vol. 5. W. A. Herdmann, ed. Royal Society of London, London, pp. 97-108.

Luque, J., and M. Oliva. 1993. Trematodes of marine fishes from the Peruvian faunistic province (Peru and Chile), with description of Lecithchirium callaoensis $\mathrm{n}$. sp. and new records. Revista de Biología Marina, Valparaiso 28:271-286.

MacGinitie, G. E. 1947. Notes on the devilfish, Mobula lucasana, and its parasites. Copeia 1947:276-278.

Manter, H. W. 1970. The terminology and occurrence of certain structures of digenetic trematodes, with special reference to the Hemiuroidea. Pages $27-33$ in K. S. Singh and B. K. Tandon, eds. H. D. Srivastava Commemorative Volume. Indian Veterinary Research Institute, Izatnagar, Uttar Pradesh, India

Markell, E. K. 1953a. Nagmia floridensis, n. sp., an anaporrhutine trematode from the Coelom of the stingray Amphotistius sabinus. Journal of Parasitology 39:45-51.

Markell, E. K. 1953b. Further observations of the anatomy of the gorgoderid trematode Probolitrema californiense. Transactions of the American Microscopic Society 72:68-77.

Markell, E. K. 1956. Probolitrema mexicana, n. sp., an anaporrhutine trematode from elasmobranchs of Baja California. Journal of Parasitology 42:56-59.

Marques, F., R. Centritto, and S. A. Stewart. 1997. Two new species of Acanthobothrium in Narcine entemedor (Rajiformes: Narcinidae) from the northwest coast of Guanacaste Peninsula, Costa Rica. Journal of Parasitology 83:927-931.

Mehra, H. R. 1960. On a new trematode Staphylorchis scoliodonii n. sp. (Family Gorgoderidae Looss, 1901; Subfamily Anaporrhutinae Looss, 1901) from South Indian shark Scoliodon sorrakowah with a phylogenetic discussion and classification of the family. Proceedings of the National Academy of Sciences of India, Section B, Biology 30:143-165.

Melouk, M. A. 1940. A new anaporrhutine trematode, Nagmia rosettensis nov. spec. Bulletin of the Faculty of Science, The Fouad I University 22:113-124.

Nagaty, H. F. 1930. A new anaporrhutine trematode genus and species Nagmia yorkei, with a review of the classification of the subfamily. Annals of Tropical Medicine and Parasitology 24:97-108.
Nagaty, H. F., and T. M. Abdel-Aal. 1961. Trematodes of fishes from the Red Sea. Part 9. Six new anaporrhutine species including a new genus. Journal of Parasitology 47:765-769.

Nelson, J. S., E. J. Crossman, H. Espinosa-Pérez, L. T. Findley, C. R. Gilbert, R. N. Lea, and J. D. Williams. 2004. Common and scientific names of fishes from the United States, Canada, and Mexico. American Fisheries Society, Special Publication 29, Bethesda, Maryland. 386 pp.

Ofenheim, E. von. 1900. Ueber eine neue Distomidengattung. Zeitschrift für Naturwissenschaften 73:145-186.

Olson, P. D., T. H. Cribb, V. V. Tkach, R. A. Bray, and D. T. Littlewood. 2003. Phylogeny and classification of the Digenea (Platyhelminthes: Trematoda). International Journal for Parasitology 33:733-755.

Samuel, M. 1952. A new species of coelomic trematode of the genus Staphylorchis from the tiger shark Galeocerdo tigrinus from Indian waters. Proceedings of the Indian Academy of Sciences, Section B, Biology 36: 169-179.

Stunkard, H. W. 1935. A new trematode, Probolitrema californiense, from the coelom of the sting ray, Myliobatis californicus. Journal of Parasitology 21: 359-364.

Tandon, R. S. 1969. A new anaporrhutine trematode (Fam. Gorgoderidae) Nagmia yamagutia $\mathrm{n}$. sp. from the ovary of the ray, Dasyatis uarnak, from Bharat (India). Annotationes Zoologicae Japonenses 42:36-39.

Tantalean, M. V., and J. S. Rodriguez. 1990. Nagmia peruviana n. sp. (Digenea: Gorgoderidae: Anaporrhutinae) un nuevo parasito de la "manta," Mobula lucasana B. y T. de la costa del Peru. Revista de Ciencias (Lima) 75:25-29.

Tantalean, M. V., B. L. Sarmiento, and P. A. Huiza. 1992 Digeneos (Trematoda) del Peru. Boletin de Lima 80: 47-84.

Tyler, G. A. 2001. Diphyllidean cestodes of the Gulf of California, México with descriptions of two new species of Echinobothrium (Cestoda: Diphyllidea). Journal of Parasitology 87:173-184.

Wilson, M. S. 1952. An emended diagnosis of the copepod genus Pupulina (Caligoida), with descriptions of new species and a redescription of the genotype. Proceedings of the U.S. National Museum 102:245-263.

Woolcock, V. 1935. Digenetic trematodes from some Australian fishes. Parasitology 27:309-331.

Yamaguti, S. 1963. Parasitic Copepoda and Branchiura of Fishes. Part I. Interscience Publishers, New York. $390 \mathrm{pp}$.

Yamaguti, S. 1971. Synopsis of Digenetic Trematodes of Vertebrates. Vol. I. Keigaku Publishing Co., Tokyo, Japan. 1,074 pp. 